\title{
Small phytoplankton contribution to the standing stocks and the total primary production in the Amundsen Sea
}

\author{
Sang H. Lee ${ }^{1}$, Bo Kyung Kim ${ }^{1}$, Yu Jeong Lim ${ }^{1}$, HuiTae Joo ${ }^{1}$, Jae Joong Kang ${ }^{1}$, Dabin Lee ${ }^{1}$, Jisoo Park ${ }^{2}$, \\ Sun-Yong $\mathrm{Ha}^{2}$, and Sang Hoon $\mathrm{Lee}^{2}$ \\ ${ }^{1}$ Department of Oceanography, Pusan National University, Geumjeong-gu, Busan 609-735, South Korea \\ ${ }^{2}$ Korea Polar Research Institute, Incheon 406-840, South Korea \\ Correspondence to: Sang H. Lee (sanglee@pnu.ac.kr)
}

Received: 20 October 2016 - Discussion started: 24 October 2016

Revised: 5 June 2017 - Accepted: 28 June 2017 - Published: 10 August 2017

\begin{abstract}
Small phytoplankton are anticipated to be more important in a recently warming and freshening ocean condition. However, little information on the contribution of small phytoplankton to overall phytoplankton production is currently available in the Amundsen Sea. To determine the contributions of small phytoplankton to total biomass and primary production, carbon and nitrogen uptake rates of total and small phytoplankton were obtained from 12 productivity stations in the Amundsen Sea. The daily carbon uptake rates of total phytoplankton averaged in this study were $0.42 \mathrm{~g} \mathrm{C} \mathrm{m}^{-2} \mathrm{~d}^{-1}\left(\mathrm{SD}= \pm 0.30 \mathrm{~g} \mathrm{C} \mathrm{m}^{-2} \mathrm{~d}^{-1}\right)$ and $0.84 \mathrm{~g} \mathrm{C} \mathrm{m}^{-2} \mathrm{~d}^{-1}\left(\mathrm{SD}= \pm 0.18 \mathrm{~g} \mathrm{C} \mathrm{m}^{-2} \mathrm{~d}^{-1}\right)$ for nonpolynya and polynya regions, respectively, whereas the daily total nitrogen (nitrate and ammonium) uptake rates were $0.12 \mathrm{~g} \mathrm{~N} \mathrm{~m}^{-2} \mathrm{~d}^{-1}\left(\mathrm{SD}= \pm 0.09 \mathrm{~g} \mathrm{~N} \mathrm{~m}^{-2} \mathrm{~d}^{-1}\right)$ and $0.21 \mathrm{~g} \mathrm{~N} \mathrm{~m}^{-2} \mathrm{~d}^{-1} \quad\left(\mathrm{SD}= \pm 0.11 \mathrm{~g} \mathrm{~N} \mathrm{~m}^{-2} \mathrm{~d}^{-1}\right)$, respectively, for non-polynya and polynya regions, all of which were within the ranges reported previously. Small phytoplankton contributed 26.9 and $27.7 \%$ to the total carbon and nitrogen uptake rates of phytoplankton in this study, respectively, which were relatively higher than the chlorophyll $a$ contribution (19.4\%) of small phytoplankton. For a comparison of different regions, the contributions for chlorophyll $a$ concentration and primary production of small phytoplankton averaged from all the non-polynya stations were 42.4 and $50.8 \%$, which were significantly higher than those (7.9 and $14.9 \%$, respectively) in the polynya region. A strong negative correlation $\left(r^{2}=0.790, p<0.05\right)$ was found between the contributions of small phytoplankton and the total daily primary production of phytoplankton in this study. This finding implies that daily primary production decreases as small phyto-
\end{abstract}

plankton contribution increases, which is mainly due to the lower carbon uptake rate of small phytoplankton than large phytoplankton.

\section{Introduction}

The Amundsen Sea is located in West Antarctica between the Ross Sea and Bellingshausen Sea (Fig. 1), which is one of the least biologically studied regions in the Southern Ocean. Recently, several international research programs (KOPRI Amundsen project, iSTAR, ASPIRE and DynaLiFe) were launched to improve the understanding of this remote area. Field-measurement data revealed that annual primary production of phytoplankton reaching to $220 \mathrm{~g} \mathrm{C} \mathrm{m}^{-2} \mathrm{yr}^{-1}$ in the Amundsen Sea polynya is as high as that of Ross Sea polynya ( $200 \mathrm{~g} \mathrm{C} \mathrm{m}^{-2} \mathrm{yr}^{-1}$ ) which was previously known for the highest productivity region in the Southern Ocean (Lee et al., 2012). Given the fact that the chlorophyll $a$ concentration averaged from all the chlorophyll $a$ measured stations was twice as high as that of the only productivity-measured stations, Lee et al. (2012) argued that the annual production in the Amundsen Sea polynya could be even 2 times higher than that of Ross Sea polynya.

Over the past several decades, a rapid climate change has been detected and subsequently physical changes have occurred in the marine ecosystem in the western Antarctic Peninsula (WAP), which was mainly based on the results from Palmer Antarctic Long-Term Ecological Research project focusing on the north of $\sim 69^{\circ} \mathrm{S}$ (Ducklow et al., 2007; Montes-Hugo et al., 2009). Recent studies revealed 


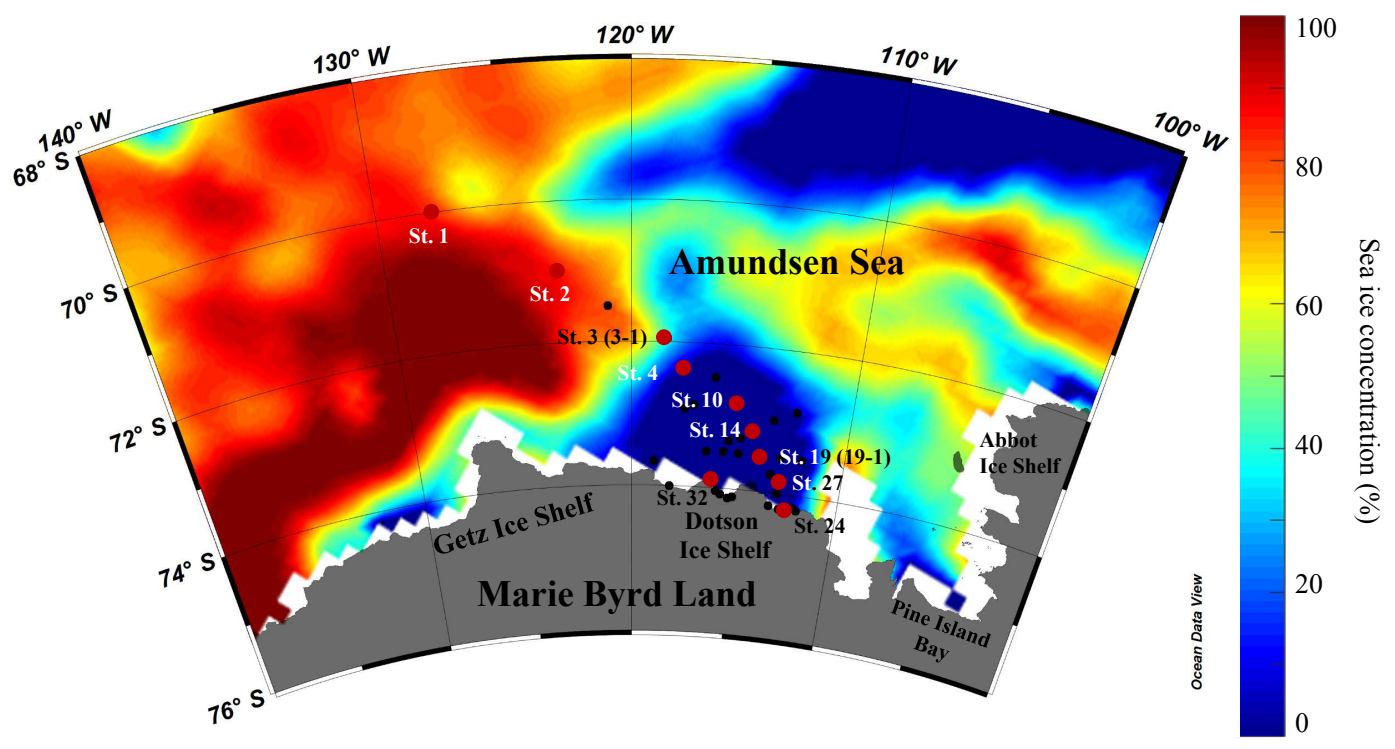

Figure 1. Sampling locations in the Amundsen Sea. Red closed circles represent productivity stations. Sea ice concentration data during the cruise period in 2013 from Nimbus-7 SMMR and DMSP SSM/I-SSMIS Passive Microwave data provided by National Snow and Ice Data Center.

that the Thwaites Glacier in Pine Island Bay is retreating fast and the ice volume loss in the nearby Getz Ice shelf is accelerating (Joughin et al., 2014; Paolo et al., 2015). Shoaling warm Circumpolar Deep Water is believed to be a main cause of the ice sheet mass loss through the ice shelf basal melt underside of the ice shelves (Yager et al., 2012; Schmidtko et al., 2014). Climate change from a cold-dry polar type to a warm-humid sub-Antarctic type has driven subsequent changes in ocean biological productivity along the WAP shelf over the recent 3 decades (Montes-Hugo et al., 2009).

Phytoplankton, as the base of oceanic food webs, can be an indicator for changes in marine ecosystems responding to environmental changes (Moline et al., 2004; Wassman et al., 2011; Arrigo and van Dijken, 2015). For example, a recurrent shift in phytoplankton community structure from large diatoms to relatively small cryptophytes could be tightly associated with changes in glacial meltwater runoff (Moline et al., 2004). To date, little information on the contribution of small phytoplankton to primary production is available in the Antarctic Ocean (Saggiomo et al., 1998), especially in the Amundsen Sea with a rapid melting of ice shelf (Yager et al., 2012; Schmidtko et al., 2014). Thus, our main objective in this study is to determine contributions of small phytoplankton to the overall total biomass and primary production of phytoplankton in the Amundsen Sea for monitoring marine ecosystem responding to environmental condition change.

\section{Materials and methods}

\subsection{Total and size-fractionated chlorophyll $a$ concentration}

Water samples for total and size-fractionated chlorophyll $a$ concentrations of phytoplankton were obtained at the 12 productivity stations in the Amundsen Sea (Fig. 1) during the KOPRI Amundsen cruise from 1 to 15 January 2014 onboard the Korean research icebreaker Araon. Based on the sea ice concentration data from the National Snow and Ice Data Center during the cruise period in 2013 (Fig. 1), our study region was further separated into polynya and non-polynya areas for comparison. Four stations (St. 1, St. 2, St. 3 and St. 31) among the 12 stations belong to the non-polynya region and the rest of the stations belong to the polynya region. St. 3 and St. 3-1 were on the fringe of the polynya area, experiencing approximately $30 \%$ sea ice cover. Following the definition of polynya as an area of open water within sea ice zone, we grouped them into non-polynya regions. Six different light depths $(100,50,30,12,5$ and $1 \%$ penetration of the surface irradiance, PAR) were determined with an LICOR underwater $4 \pi$ light sensor. Total chlorophyll $a$ concentrations were measured at the six different light depths $(100,50,30,12,5$ and $1 \%$ of PAR). For size-fractionated chlorophyll $a$ concentrations, water samples were collected at three light depths $(100,30$ and $1 \%)$. Water samples $(0.3-$ $0.5 \mathrm{~L}$ ) for total chlorophyll $a$ concentrations were filtered using Whatman glass fiber filters (GF/F; $25 \mathrm{~mm}$ ). For different size-fractionated chlorophyll $a$ concentrations water samples $(0.7-1 \mathrm{~L})$ were passed sequentially through 20 and $5 \mu \mathrm{m} \mathrm{Nu}-$ cleopore filters $(47 \mathrm{~mm})$ and $0.7 \mu \mathrm{m} \mathrm{GF} / \mathrm{F}$ filters $(47 \mathrm{~mm})$. 
Table 1. Percentage contributions (\%) of small phytoplankton to depth-integrated total concentrations of chlorophyll $a$, POC, PON and carbon and nitrogen uptake rates in the Amundsen Sea.

\begin{tabular}{lrrrrrrr}
\hline & Chlorophyll $a$ & POC & PON & $\begin{array}{r}\text { Daily carbon } \\
\text { uptake rate }\end{array}$ & $\begin{array}{r}\text { Daily nitrate } \\
\text { uptake rate }\end{array}$ & $\begin{array}{r}\text { Daily ammonium } \\
\text { uptake rate }\end{array}$ & $\begin{array}{r}\text { Total nitrogen } \\
\text { uptake rate }\end{array}$ \\
\hline All stations & $19.4 \pm 26.0$ & $41.1 \pm 10.6$ & $41.3 \pm 11.5$ & $26.9 \pm 29.3$ & $21.5 \pm 11.1$ & $38.7 \pm 24.9$ & $27.7 \pm 14.4$ \\
Non-polynya & $42.4 \pm 37.2$ & $49.5 \pm 14.4$ & $50.0 \pm 15.1$ & $50.8 \pm 42.8$ & $28.2 \pm 15.9$ & $52.8 \pm 40.5$ & $36.2 \pm 23.0$ \\
Polynya & $7.9 \pm 3.5$ & $36.9 \pm 4.6$ & $37.0 \pm 6.9$ & $14.9 \pm 8.4$ & $18.1 \pm 6.8$ & $31.6 \pm 10.1$ & $23.5 \pm 6.0$ \\
\hline
\end{tabular}

After the filters were extracted using the method described by Kim et al. (2015), all chlorophyll $a$ concentrations were subsequently determined onboard using a Trilogy fluorometer (Turner Designs, USA). The methods and calculations for chlorophyll $a$ were based on Parsons et al. (1984).

\subsection{Carbon and nitrogen uptake experiments}

Water samples were collected for and carbon and nitrogen uptake measurements of phytoplankton. Using a dual stable isotope technique (Lee et al., 2012; Kim et al., 2015), the experiments of carbon and nitrogen uptake rates of phytoplankton were conducted at 12 selected productivity stations including two revisited stations (St. 3-1 and St. 19-1) when on-deck incubations were available during daytime at oceanographic survey stations. Water samples from the six light depths for the uptake experiments were obtained from a CTD-rosette sampler system equipped with twenty-four $10 \mathrm{~L}$ Niskin bottles. Water sample from each light depth was transferred into different screened polycarbonate incubation bottles $(1 \mathrm{~L})$ which matched each light depth. The bottles were placed in large polycarbonate incubators cooled with running surface seawater on deck under natural light conditions for 4-5 h, after the water samples in the incubation bottles were inoculated with labeled carbon $\left(\mathrm{NaH}^{13} \mathrm{CO}_{3}\right)$ and nitrate $\left(\mathrm{K}^{15} \mathrm{NO}_{3}\right)$ or ammonium $\left({ }^{15} \mathrm{NH}_{4} \mathrm{Cl}\right)$ substrates. After 4-5 $\mathrm{h}$ incubations, the incubated waters were well mixed and distributed into two filtration sets for the carbon and nitrogen uptake rates of total $(>0.7 \mu \mathrm{m})$ and small-sized cells $(0.7-5 \mu \mathrm{m})$. Small-sized cells are generally defined as small phytoplankton in comparison to large diatoms $(>5 \mu \mathrm{m})$ (Robineau et al., 1994; references therein). The incubated waters $(0.3 \mathrm{~L})$ for total uptake rates were filtered through pre-combusted $\mathrm{GF} / \mathrm{F}$ filters ( $25 \mathrm{~mm}$ diameter), whereas waters samples $(0.5 \mathrm{~L})$ for the uptake rates of small phytoplankton were passed through $5 \mu \mathrm{m}$ Nuclepore filters $(47 \mathrm{~mm})$ to remove large phytoplankton cells $(>5 \mu \mathrm{m})$ and then the filtrate was passed through pre-combusted GF/F $(25 \mathrm{~mm})$ for the small phytoplankton (Lee et al., 2013). The values for large phytoplankton in this study were obtained from the difference between small and total fractions (Lee et al., 2013). The filters were immediately preserved at $-80^{\circ} \mathrm{C}$ until mass spectrometric analysis. After acid fuming overnight to remove carbonate, the concentrations of particulate organic carbon (POC) and nitrogen (PON) and the abundance of ${ }^{13} \mathrm{C}$ and ${ }^{15} \mathrm{~N}$ were determined by a Finnigan Delta $+\mathrm{XL}$ mass spectrometer at the Alaska Stable Isotope Facility, USA. All contribution results of small phytoplankton in this study were estimated from comparison of small phytoplankton to total phytoplankton integral values from 100 to $1 \%$ light depth at each station based on the trapezoidal rule. Daily carbon and nitrogen uptake rates of phytoplankton were based on our hourly uptake rates measured in this study and a $24 \mathrm{~h}$ photoperiod per day during the summer period in the Amundsen Sea (Lee et al., 2012).

\section{Results}

\subsection{Chlorophyll $a$, POC and PON contributions of small phytoplankton}

The depth-integrated total (large + small phytoplankton) chlorophyll $a$ concentration was $11.1-80.3 \mathrm{mg} \mathrm{Chl} a \mathrm{~m}^{-2}$ (mean $\pm \mathrm{SD}=57.4 \pm 25.2 \mathrm{mgChl} a \mathrm{~m}^{-2}$ ) in this study (Fig. 2). The contribution of small phytoplankton to the total chlorophyll $a$ concentration was 4.9-76.5\% (19.4 $\pm 26.0 \%)$. Large phytoplankton $(>5 \mu \mathrm{m})$ were generally predominant (approximately 80\%) based on different-sized chlorophyll $a$ concentrations. For a regional comparison, the average contributions of small phytoplankton to the total chlorophyll $a$ concentration were $42.4 \%( \pm 37.2 \%)$ and $7.9 \%( \pm 3.5 \%)$ for non-polynya and polynya regions, respectively (Table 1). The chlorophyll $a$ contribution of small phytoplankton was larger in the non-polynya region than in the polynya region although they were not significantly different $(t$ test, $p>0.05$ ).

The depth-integrated total POC concentration of phytoplankton showed no large spatial variation ranging from 4.72 to $9.22 \mathrm{mg} \mathrm{C} \mathrm{m}^{-2}\left(7.40 \pm 1.55 \mathrm{mg} \mathrm{C} \mathrm{m}^{-2}\right)$ (Fig. 3). In comparison, the depth-integrated total $\mathrm{PON}$ concentration of phytoplankton was $0.76-1.74 \mathrm{mg} \mathrm{N} \mathrm{m}^{-2}(1.33 \pm$ $0.32 \mathrm{mg} \mathrm{N} \mathrm{m}^{-2}$ ). The POC contribution of small phytoplankton was $30.7-65.5 \%(41.1 \pm 10.6 \%)$, whereas the PON contribution was $30.8-67.2 \%(41.3 \pm 11.5 \%)$ in the Amundsen Sea (Fig. 3). Specifically, the POC and PON contributions of small phytoplankton averaged from all the productivity stations in the polynya region were $36.9 \%( \pm 4.6 \%)$ and $37.0 \%$ $( \pm 6.9 \%)$, respectively, whereas they were $49.5 \%( \pm 14.4 \%)$ and $50.0 \%( \pm 15.1 \%)$, respectively, in the non-polynya re- 


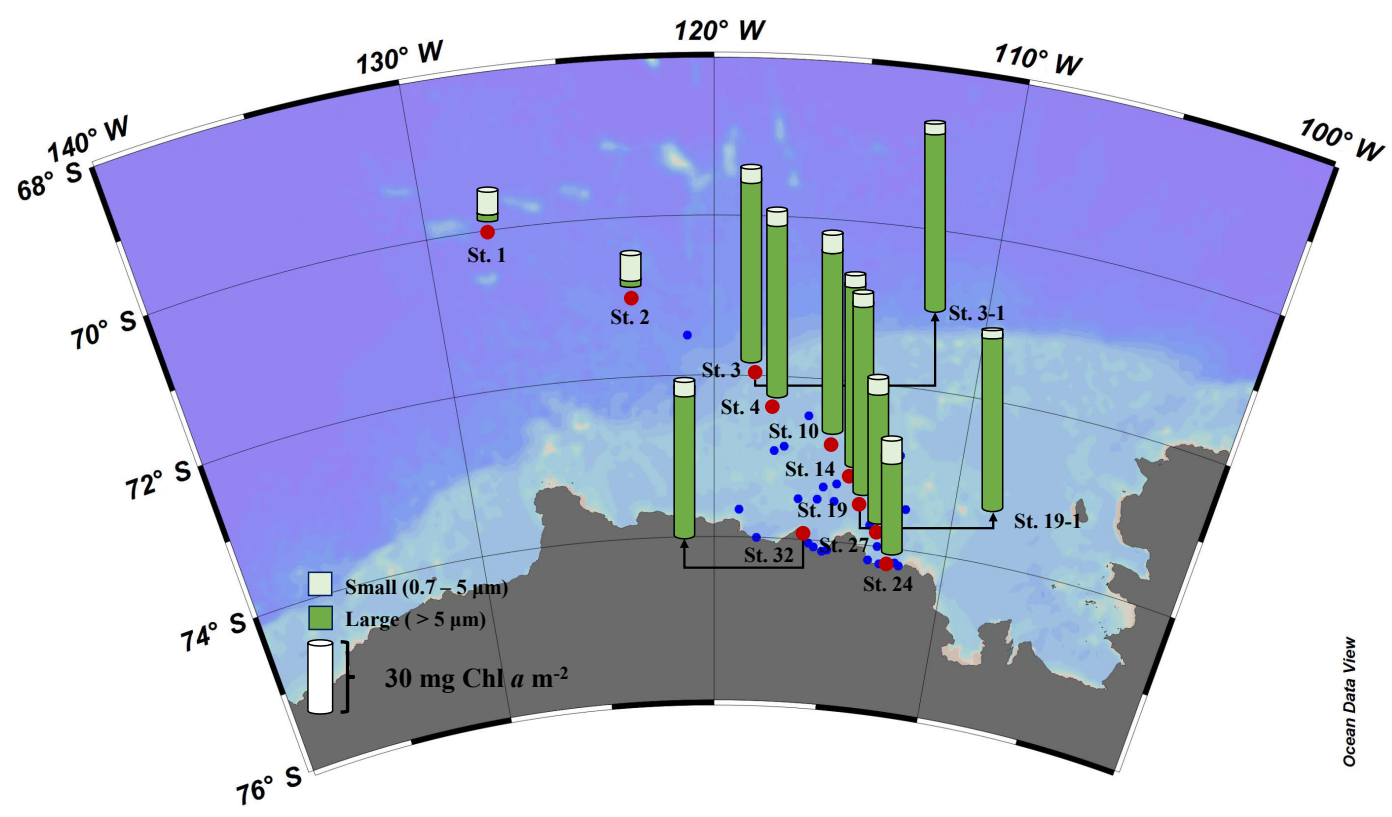

Figure 2. Water-column-integrated chlorophyll $a$ concentrations $\left(\mathrm{mg} \mathrm{Chl} a \mathrm{~m}^{-2}\right)$ of small $(0.7-5 \mu \mathrm{m})$ and large (>5 $\left.\mu \mathrm{m}\right)$ phytoplankton at the productivity stations in the Amundsen Sea.

gion (Table 1). The POC and PON contributions of small phytoplankton were not statistically different between the polynya and non-polynya regions ( $t$ test, $p>0.05$ ).

\subsection{Carbon uptake rate contributions of small phytoplankton}

The depth-integrated total daily carbon uptake rate of phytoplankton (large + small phytoplankton) was 150.4$1213.4 \mathrm{mg} \mathrm{C} \mathrm{m}^{-2} \mathrm{~d}^{-1}\left(696.5 \pm 298.4 \mathrm{mg} \mathrm{C} \mathrm{m}^{-2} \mathrm{~d}^{-1}\right)$ in this study (Fig. 4). In contrast, the rate of small phytoplankton was 58.6-266.4 $\mathrm{mg} \mathrm{C} \mathrm{m}^{-2} \mathrm{~d}^{-1}\left(124.9 \pm 62.4 \mathrm{mg} \mathrm{C} \mathrm{m}^{-2} \mathrm{~d}^{-1}\right)$. Small phytoplankton contributed $26.9 \%( \pm 29.3 \%)$ to total daily carbon uptake rate of total phytoplankton.

Specifically, the total daily carbon uptake rate of phytoplankton was $150.4-796.4 \mathrm{mg} \mathrm{C} \mathrm{m}^{-2} \mathrm{~d}^{-1}$ $\left(415.0 \pm 298.2 \mathrm{~m} \mathrm{C} \mathrm{m}^{-2} \mathrm{~d}^{-1}\right)$ in the non-polynya region, whereas it was $654.8-1213.4 \mathrm{mg} \mathrm{C} \mathrm{m}^{-2} \mathrm{~d}^{-1}$ $\left(837.3 \pm 184.1 \mathrm{mg} \mathrm{C} \mathrm{m}^{-2} \mathrm{~d}^{-1}\right)$ in the polynya region. The total daily carbon uptake rates of phytoplankton were significantly higher $(t$ test, $p<0.05)$ in the polynya region than the non-polynya region. The rate of small phytoplankton was 58.6-193.6 $\mathrm{mg} \mathrm{C} \mathrm{m}^{-2} \mathrm{~d}^{-1} \quad\left(126.5 \pm 55.2 \mathrm{mg} \mathrm{C} \mathrm{m}^{-2} \mathrm{~d}^{-1}\right)$ in the non-polynya region, whereas it was 62.2$266.4 \mathrm{mg} \mathrm{C} \mathrm{m}^{-2} \mathrm{~d}^{-1} \quad\left(124.1 \pm 69.3 \mathrm{mg} \mathrm{C} \mathrm{m}^{-2} \mathrm{~d}^{-1}\right) \quad$ in the polynya region. The daily carbon uptake rates of small phytoplankton were not significantly different ( $t$ test, $p>0.05$ ) between the polynya and non-polynya stations. The average contributions of small phytoplankton to total daily carbon uptake rates were $50.8 \%( \pm 42.8 \%)$ and $14.9 \%$ $( \pm 8.4 \%)$, respectively, for the non-polynya and polynya regions (Table 1). The average contributions were largely different between the polynya and non-polynya regions but they were not statistically significant ( $t$ test, $p>0.05$ ).

\subsection{Nitrogen uptake rate contributions of small phytoplankton}

The depth-integrated total daily nitrate uptake rate of phytoplankton (large + small phytoplankton) was 34.0$174.2 \mathrm{mg} \mathrm{N} \mathrm{m}^{-2} \mathrm{~d}^{-1}\left(93.7 \pm 43.2 \mathrm{mg} \mathrm{N} \mathrm{m}^{-2} \mathrm{~d}^{-1}\right)$, whereas the rate of small phytoplankton was $6.1-40.9 \mathrm{mg} \mathrm{N} \mathrm{m}^{-2} \mathrm{~d}^{-1}$ $\left(19.0 \pm 11.3 \mathrm{mg} \mathrm{N} \mathrm{m}^{-2} \mathrm{~d}^{-1}\right)$ in this study (Fig. 5). Small phytoplankton contributed $21.5 \%( \pm 11.1 \%)$ to total daily nitrate uptake rates. In comparison, the total daily ammonium uptake rate of phytoplankton was 12.4$173.8 \mathrm{mg} \mathrm{N} \mathrm{m}^{-2} \mathrm{~d}^{-1} \quad\left(86.7 \pm 75.9 \mathrm{mg} \mathrm{N} \mathrm{m}^{-2} \mathrm{~d}^{-1}\right)$, whereas the rate of small phytoplankton was $9.1-81.1 \mathrm{mg} \mathrm{N} \mathrm{m}^{-2} \mathrm{~d}^{-1}$ $\left(25.7 \pm 21.1 \mathrm{mg} \mathrm{N} \mathrm{m}^{-2} \mathrm{~d}^{-1}\right)$ in this study (Fig. 6). Small phytoplankton contributed $38.7 \%( \pm 24.9 \%)$ to total daily ammonium uptake rates. The contributions of small phytoplankton were significantly higher in ammonium uptake rate than nitrate uptake rate $(t$ test, $p<0.05)$.

For different regions, the total daily nitrate uptake rates of phytoplankton were $34.0-142.1 \mathrm{mg} \mathrm{N} \mathrm{m}^{-2} \mathrm{~d}^{-1}$ $\left(71.9 \pm 48.4 \mathrm{mg} \mathrm{N} \mathrm{m}^{-2} \mathrm{~d}^{-1}\right)$ in the non-polynya region and $44.2-174.2 \mathrm{mg} \mathrm{N} \mathrm{m}^{-2} \mathrm{~d}^{-1} \quad\left(104.6 \pm 39.0 \mathrm{mg} \mathrm{N} \mathrm{m}^{-2} \mathrm{~d}^{-1}\right)$ in the polynya region, respectively. In comparison, the daily nitrate uptake rates of small phytoplankton were 7.5-26.6 $\mathrm{mg} \mathrm{N} \mathrm{m}^{-2} \mathrm{~d}^{-1} \quad\left(16.7 \pm 7.8 \mathrm{mg} \mathrm{N} \mathrm{m}^{-2} \mathrm{~d}^{-1}\right) \quad$ and $6.1-40.9 \mathrm{mg} \mathrm{N} \mathrm{m}^{-2} \mathrm{~d}^{-1} \quad\left(20.1 \pm 13.1 \mathrm{mg} \mathrm{N} \mathrm{m}^{-2} \mathrm{~d}^{-1}\right)$, respectively, for the non-polynya and polynya regions. 


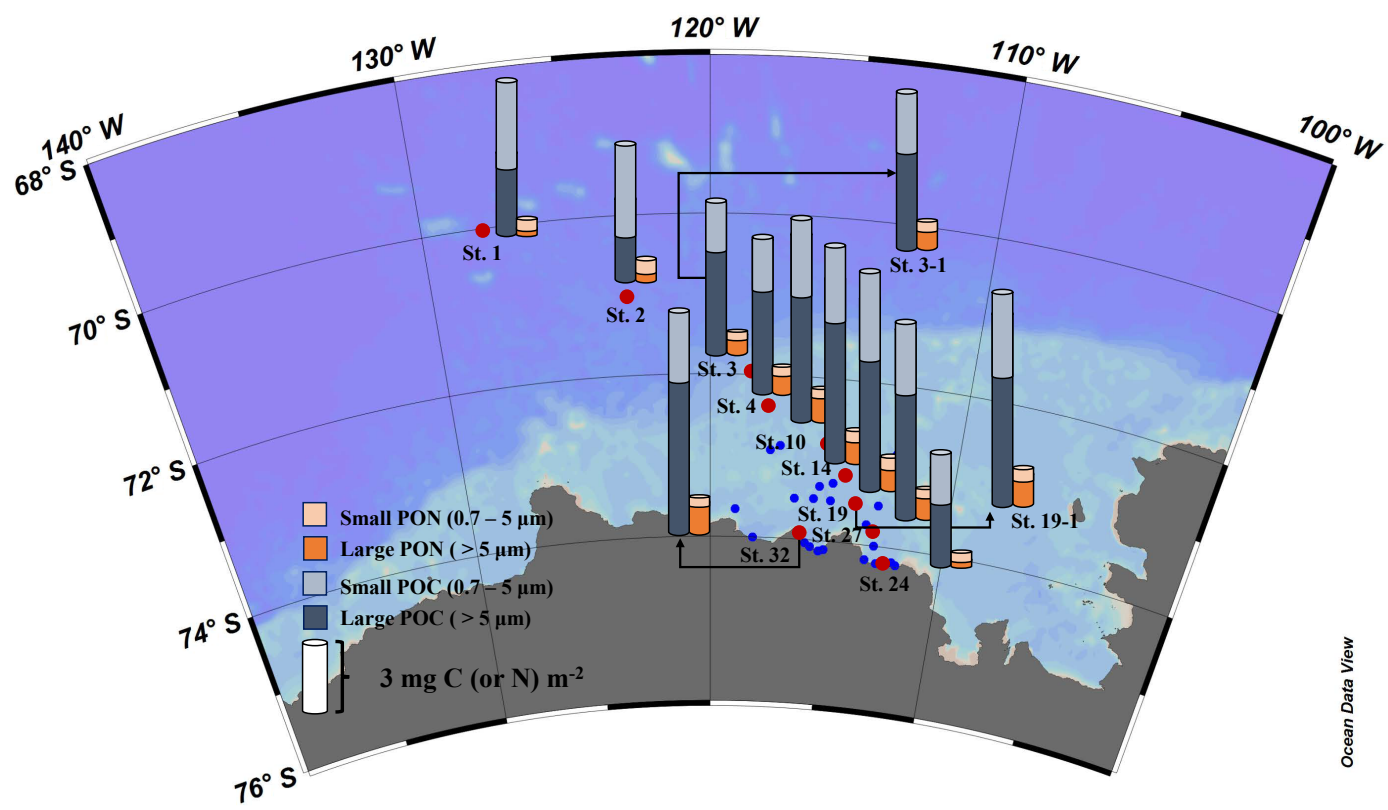

Figure 3. Water-column-integrated concentrations of POC $\left(\mathrm{mg} \mathrm{C} \mathrm{m}^{-2}\right)$ and PON $\left(\mathrm{mg} \mathrm{N} \mathrm{m}^{-2}\right)$ of small $(0.7-5 \mu \mathrm{m})$ and large $(>5 \mu \mathrm{m})$ phytoplankton.

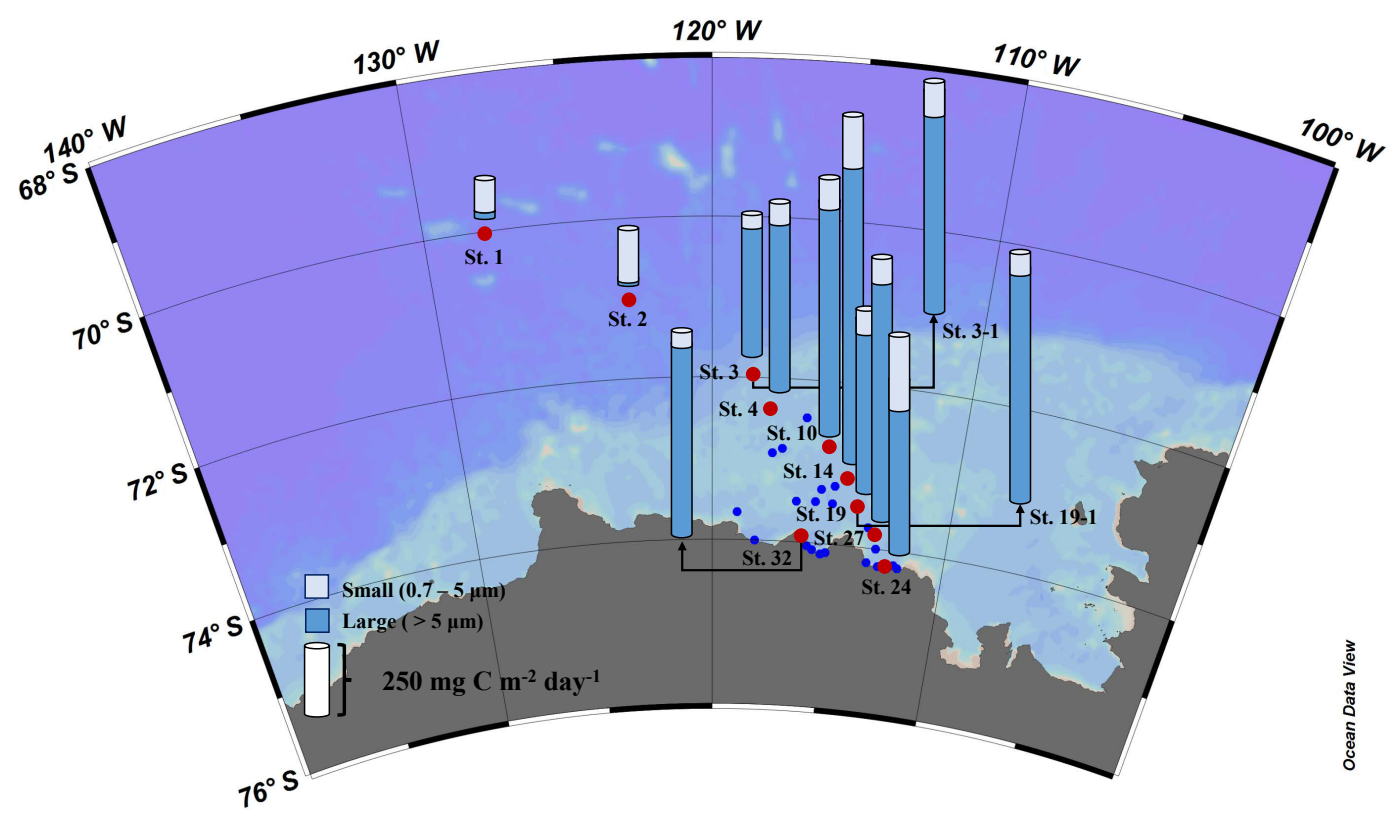

Figure 4. Water-column-integrated daily carbon uptake rates $\left(\mathrm{mg} \mathrm{C} \mathrm{m}^{-2} \mathrm{~d}^{-1}\right)$ of small $(0.7-5 \mu \mathrm{m})$ and large $(>5 \mu \mathrm{m})$ phytoplankton.

The contributions of small phytoplankton to the total daily nitrate uptake rates were $28.2 \%( \pm 15.9 \%)$ in the non-polynya region and $18.1 \%( \pm 6.8 \%)$ in the polynya region, respectively (Table 1 ). The total daily ammonium uptake rates of total phytoplankton were 12.3 and $\quad 106.1 \mathrm{mg} \mathrm{N} \mathrm{m}^{-2} \mathrm{~d}^{-1} \quad\left(49.7 \pm 41.2 \mathrm{mg} \mathrm{N} \mathrm{m}^{-2} \mathrm{~d}^{-1}\right) \quad$ in the non-polynya region and $18.1-269.3 \mathrm{mg} \mathrm{N} \mathrm{m}^{-2} \mathrm{~d}^{-1}$ $\left(105.2 \pm 84.6 \mathrm{mg} \mathrm{N} \mathrm{m}^{-2} \mathrm{~d}^{-1}\right)$ in the polynya region.
In comparison, the rates of small phytoplankton were 9.1-22.4 $\mathrm{mg} \mathrm{N} \mathrm{m}^{-2} \mathrm{~d}^{-1} \quad\left(15.8 \pm 6.4 \mathrm{mg} \mathrm{N} \mathrm{m}^{-2} \mathrm{~d}^{-1}\right) \quad$ in the non-polynya region and $9.9-81.1 \mathrm{mg} \mathrm{N} \mathrm{m}^{-2} \mathrm{~d}^{-1}$ $\left(30.7 \pm 24.5 \mathrm{mg} \mathrm{N} \mathrm{m}^{-2} \mathrm{~d}^{-1}\right)$ in the polynya region. Small phytoplankton contributed $52.8 \%( \pm 40.5 \%)$ and $31.6 \%$ $( \pm 10.1 \%)$ to the total daily ammonium uptake rates in the non-polynya and polynya regions, respectively, which were not significantly different ( $t$ test, $p>0.05$ ). 


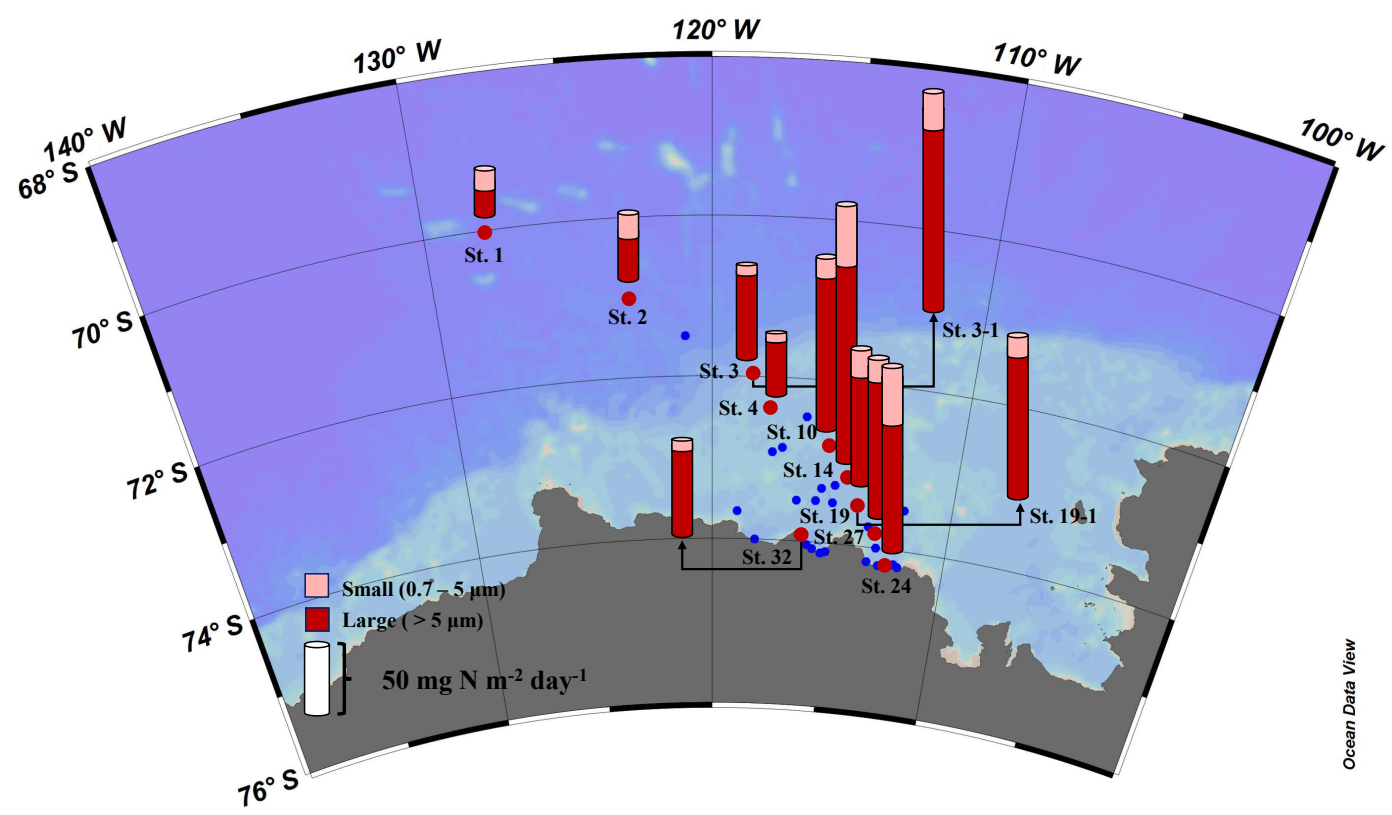

Figure 5. Water-column-integrated daily nitrate uptake rates $\left(\mathrm{mg} \mathrm{N} \mathrm{m}^{-2} \mathrm{~d}^{-1}\right)$ of small $(0.7-5 \mu \mathrm{m})$ and large $(>5 \mu \mathrm{m})$ phytoplankton.

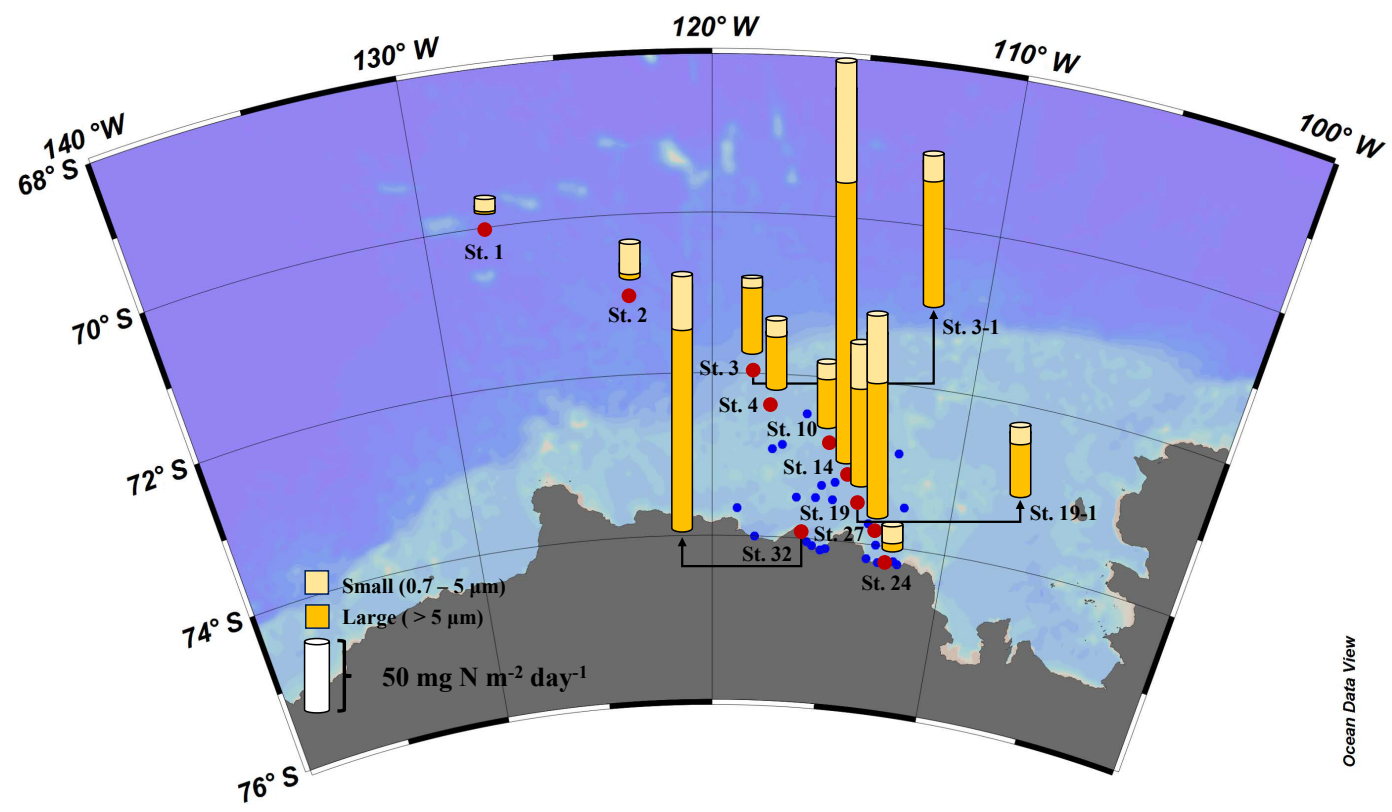

Figure 6. Water-column-integrated daily ammonium uptake rates $\left(\mathrm{mg} \mathrm{N} \mathrm{m}^{-2} \mathrm{~d}^{-1}\right)$ of small $(0.7-5 \mu \mathrm{m})$ and large $(>5 \mu \mathrm{m})$ phytoplankton.

The total integral daily nitrogen uptake rate (nitrate + ammonium uptake rates) of phytoplankton was 46.4$443.5 \mathrm{mg} \mathrm{N} \mathrm{m}^{-2} \mathrm{~d}^{-1}\left(180.4 \pm 106.7 \mathrm{mg} \mathrm{N} \mathrm{m}^{-2} \mathrm{~d}^{-1}\right)$ in this study. For the non-polynya and polynya regions, they were $46.4-248.1 \mathrm{mg} \mathrm{N} \mathrm{m}^{-2} \mathrm{~d}^{-1}\left(121.6 \pm 89.3 \mathrm{mg} \mathrm{N} \mathrm{m}^{-2} \mathrm{~d}^{-1}\right)$ and $91.7-443.5 \mathrm{mg} \mathrm{N} \mathrm{m}^{-2} \mathrm{~d}^{-1} \quad\left(209.8 \pm 107.3 \mathrm{mg} \mathrm{N} \mathrm{m}^{-2} \mathrm{~d}^{-1}\right)$, respectively. In comparison, the total integral daily nitrogen uptake rates of small phytoplankton were 16.6$46.6 \mathrm{mg} \mathrm{N} \mathrm{m}^{-2} \mathrm{~d}^{-1} \quad\left(32.5 \pm 13.2 \mathrm{mg} \mathrm{N} \mathrm{m}^{-2} \mathrm{~d}^{-1}\right) \quad$ and
$17.6-122.0 \mathrm{mg} \mathrm{N} \mathrm{m}^{-2} \mathrm{~d}^{-1} \quad\left(50.8 \pm 32.4 \mathrm{mg} \mathrm{N} \mathrm{m}^{-2} \mathrm{~d}^{-1}\right)$ for the non-polynya and polynya regions, respectively. Small phytoplankton contributed $36.2 \%( \pm 23.0 \%)$ to the total integral daily nitrogen uptake rates in the non-polynya region, whereas they contributed $23.5 \%( \pm 6.0 \%)$ for the polynya region (Table 1 ). The integral daily nitrogen uptake rates and contributions of small phytoplankton were not statistically different between the non-polynya and polynya regions. 


\section{Discussion and conclusion}

The total daily carbon uptake rates of phytoplankton averaged for the non-polynya and polynya regions were $0.42 \mathrm{~g} \mathrm{C} \mathrm{m}^{-2} \mathrm{~d}^{-1}\left( \pm 0.30 \mathrm{~g} \mathrm{C} \mathrm{m}^{-2} \mathrm{~d}^{-1}\right)$ and $0.84 \mathrm{~g} \mathrm{C} \mathrm{m}^{-2} \mathrm{~d}^{-1}$ $\left( \pm 0.18 \mathrm{~g} \mathrm{C} \mathrm{m}^{-2} \mathrm{~d}^{-1}\right)$, respectively, in this study. According to the previous reports in the Amundsen Sea (Lee et al., 2012; Kim et al., 2015), the total daily carbon uptake rates ranged from 0.2 to $0.12 \mathrm{~g} \mathrm{C} \mathrm{m}^{-2} \mathrm{~d}^{-1}$ in the non-polynya region. Our rate $\left(0.42 \mathrm{~g} \mathrm{C} \mathrm{m}^{-2} \mathrm{~d}^{-1}\right)$ in the non-polynya region is somewhat higher than those reported previously but they are not significantly different ( $t$ test, $p>0.05$ ). In comparison, our total daily carbon uptake rate in the polynya region $\left(0.84 \mathrm{~g} \mathrm{C} \mathrm{m}^{-2} \mathrm{~d}^{-1}\right)$ is lower than that $\left(2.2 \mathrm{~g} \mathrm{C} \mathrm{m}^{-2} \mathrm{~d}^{-1}\right)$ of Lee et al. (2012) and higher than that $\left(0.2 \mathrm{~g} \mathrm{C} \mathrm{m}^{-2} \mathrm{~d}^{-1}\right)$ of Kim et al. (2015). The carbon uptake rates of phytoplankton in Lee et al. (2012) and Kim et al. (2015) were measured during the periods 21 December 2010 to 23 January 2011 and 11 February to 14 March 2012, respectively. Our measurements in this study were executed mainly during the period 1-15 January 2014. For the Amundsen polynya region, a large seasonal variation in the total daily carbon uptake rate of phytoplankton was already reported by Kim et al. (2015) and Arrigo et al. (2012) based on field-measured data and satellitederived approach, respectively. Generally, late December is the time of peak uptake rate in this region (Arrigo et al., 2012). Previous studies reported that the total daily nitrogen uptake rates in non-polynya region were $0.24 \mathrm{~g} \mathrm{~N} \mathrm{~m}^{-2} \mathrm{~d}^{-1}$ during the period 21 December 2010 to 23 January 2011 and $0.04 \mathrm{~g} \mathrm{~N} \mathrm{~m}^{-2} \mathrm{~d}^{-1}$ during the period 11 February to 14 March 2012, whereas the uptake rates in polynya region were $0.93 \mathrm{~g} \mathrm{~N} \mathrm{~m}^{-2} \mathrm{~d}^{-1}$ in 2010/2011 and $0.06 \mathrm{~g} \mathrm{~N} \mathrm{~m}^{-2} \mathrm{~d}^{-1}$ in 2012 in the Amundsen Sea (Lee et al., 2012; Kim et al., 2015). Our total daily nitrogen uptake rates of phytoplankton in non-polynya $\left(0.12 \pm 0.09 \mathrm{~g} \mathrm{~N} \mathrm{~m}^{-2} \mathrm{~d}^{-1}\right)$ and polynya regions $\left(0.21 \pm 0.11 \mathrm{~g} \mathrm{~N} \mathrm{~m}^{-2} \mathrm{~d}^{-1}\right)$ were between the ranges of two previous studies (Lee et al., 2012; Kim et al., 2015). Based on the nitrate and ammonium uptake rates in this study, $f$ ratios (nitrate uptake rate/nitrate + ammonium uptake rates) averaged for non-polynya and polynya regions were $0.62( \pm 0.08)$ and $0.54( \pm 0.20)$, respectively. These ratios were also between the ranges of two previous studies. Although they were not significantly different because of a large spatial variation, larger $f$ ratios in non-polynya than in polynya region are consistent with the results of the previous studies (Lee et al., 2012; Kim et al., 2015). At this point, we do not have a solid explanation for that and a further future study is needed for the higher $f$-ratio mechanism in nonpolynya region.

The percentage contributions of small phytoplankton to chlorophyll $a$, POC/PON, daily carbon and nitrogen uptake rates are shown in Table 1 . The result of significantly higher chlorophyll $a$ contribution than the POC contribution of small phytoplankton is consistent with the result in the Chukchi Sea, Arctic Ocean reported by Lee et al. (2013).
They explain that higher POC content per chlorophyll $a$ unit of small phytoplankton could have caused the higher POC contribution in their study (Lee et al., 2013). Given C / N ratio $(6.6 \pm 0.6)$ and $\delta^{13} \mathrm{C}(-25.9 \pm 1.0 \%)$ of sample filters attained for POC and PON in this study, our filtered samples are believed to be mainly phytoplankton-originated POC and PON (Kim et al., 2016). Thus, a significant potential overestimated contribution of POC caused by non-phytoplankton materials could be excluded for the higher POC contribution than chlorophyll $a$ contribution of small phytoplankton. Therefore, small phytoplankton contributions based on conventional assessments of chlorophyll $a$ concentration might lead to an underestimated contribution of small phytoplankton (Lee et al., 2013). In fact, several authors argue that chlorophyll $a$ concentration might not be a good index for phytoplankton biomass since it depends largely on environmental factors such as nutrient and light conditions, as well as dominant groups and physiological status of phytoplankton (Desortová, 1981; Behrenfeld et al., 2005; Kruskopf and Flynn, 2006; Behrenfeld and Boss, 2006). However, the effects of non-phytoplankton carbon materials such as extracellular carbon mucilage cannot be completely excluded for the POC contribution as discussed below.

The overall contributions of carbon $(26.9 \%)$ and nitrogen $(27.7 \%)$ uptake rates of small phytoplankton at all the productivity stations in this study are relatively higher than the chlorophyll $a$ contribution of small phytoplankton but they are not statistically different ( $t$ test, $p>0.05$ ). In general, the contribution of daily ammonium uptake rate of small phytoplankton is significantly ( $t$ test, $p<0.05$ ) higher than the contribution of daily nitrate uptake rate of small phytoplankton at all the stations in this study. This is well known for the ammonium preference of small phytoplankton in various regions (Koike et al., 1986; Tremblay et al., 2000; Lee et al., 2008, 2013).

In terms of the contributions in different regions, all the contributions (chlorophyll $a$, POC/PON, carbon and nitrogen uptake rates) of small phytoplankton were higher in the non-polynya region than in the polynya region (Table 1). In addition, the chlorophyll $a$ contribution of small phytoplankton $(7.9 \pm 3.5 \%)$ was significantly $(t$ test, $p<0.05)$ lower than the POC contribution $(36.9 \pm 4.6 \%)$ in the polynya region, whereas they were not statistically different in the non-polynya region (Table 1). This indicates that small phytoplankton contributed more to the total POC than to the chlorophyll $a$ concentration in the polynya region. We do not have species compositions of phytoplankton in this study, but previous results reported that Phaeocystis spp. are dominant in the Amundsen Sea polynya region (Lee et al., 2012). Generally, Phaeocystis spp. release a large amount (up to $46 \%$ ) of extracellular carbon mucilage which constitutes their colonial form (Matrai et al., 1995). This non-phytoplankton carbon material without chlorophyll $a$ might have caused a high POC contribution of small phytoplankton in the polynya region in this study. In fact, the contribution of the daily carbon 


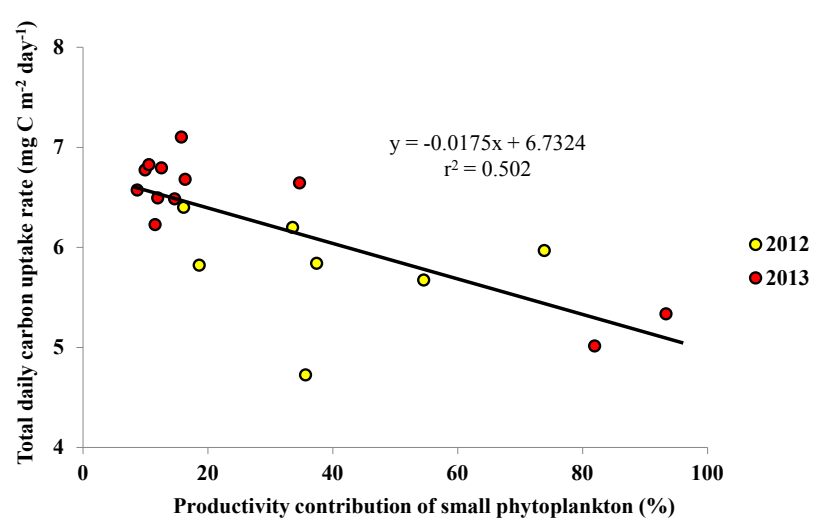

Figure 7. Relationship between productivity contributions (\%) of small phytoplankton and the total daily carbon uptake rates $\left(\mathrm{mg} \mathrm{C} \mathrm{m}^{-2} \mathrm{~d}^{-1}\right.$ ) of phytoplankton (large + small). The total daily carbon uptake rates were transformed into natural logs for a linear regression. Red circles represent data obtained in 2013 (this study). Yellow circles representing 2012 data (unpublished) were included for a better regression.

uptake rates of small phytoplankton $(14.9 \pm 8.4 \%)$ was not as high as the POC contribution $(36.9 \pm 4.6 \%)$ in the polynya region. The chlorophyll $a$ contributions of small phytoplankton were lower than those of the daily carbon uptake rate in this study, which is consistent with the results from polynya and marginal ice zone stations in the Ross Sea, Antarctica, during austral spring and summer (Saggiomo et al., 1998). They reported that the chlorophyll $a$ and primary production contributions of pico-phytoplankton $(<2 \mu \mathrm{m})$ were 29 and $40 \%$ at polynya stations, whereas the contributions were 17 and $32 \%$ at marginal ice zone stations, respectively. In the polynya region, they found much higher contributions in chlorophyll $a$ and primary production of small phytoplankton than those in this study, although their size of the small phytoplankton is somewhat smaller than our size $(<5 \mu \mathrm{m})$.

In conclusion, we found a strong negative correlation $\left(r^{2}=0.502, p<0.05\right)$ between the productivity contributions of small phytoplankton and total daily carbon uptake rates of total phytoplankton in the Amundsen Sea (Fig. 7), which indicates that daily primary production decreases as small phytoplankton contribution increases. With respect to food quality of small phytoplankton as a basic food source to herbivores, macromolecular compositions such as proteins, lipids and carbohydrates as photosynthetic end products will be needed for a better understanding of a small-cell-dominant marine ecosystem in response to environmental changes (Lee et al., 2013). According to Kang et al. (2017), small phytoplankton assimilate more food materials and calorific contents per unit of chlorophyll $a$ concentration and thus provide more contributions with respect to the energy aspect than do other phytoplankton communities in the East/Japan Sea. However, this change in dominant phytoplankton community from large to small cells will likely cause further alteration in the higher trophic levels because of the prey size available to higher trophic grazers (Moline et al., 2004). Monitoring the contributions of small phytoplankton to total biomass and primary production of the total phytoplankton community is important, as it provides a valuable indicator to sense environmental changes and consequently their potential influence on higher trophic animals in marine ecosystem.

Data availability. Data are available and can be requested from the corresponding author (sanglee@ pusan.ac.kr).

Competing interests. The authors declare that they have no conflict of interest.

Acknowledgements. We thank the captain and crew members of the Korean research icebreaker Araon, for their outstanding assistance during the cruise. This research was supported by the Korea Polar Research Institute (KOPRI; PP15020).

Edited by: Gerhard Herndl

Reviewed by: Andrew Davidson and two anonymous referees

\section{References}

Arrigo, K. R. and van Dijken, G. L.: Continued increases in Arctic Ocean primary production, Prog. Oceanogr., 136, 60-70, 2015.

Arrigo, K. R., Lowry, K. E., and van Dijken, G. L.: Annual changes in sea ice and phytoplankton in polynyas of the Amundsen Sea, Antarctica, Deep-Sea Res. Pt. II, 71, 5-15, 2012.

Behrenfeld, M. J. and Boss, E.: Beam attenuation and chlorophyll concentration as alternative optical indices of phytoplankton biomass, J. Mar. Res., 64, 431-451, 2006.

Behrenfeld, M. J., Boss, E., Siegel, D. A. and Shea, D. M.: Carbon-based ocean productivity and phytoplankton physiology from space, Global Biogeochem. Cy., 19, GB1006, https://doi.org/10.1029/2004GB002299, 2005.

Desortová, B.: Relationship between chlorophyll-a concentration and phytoplankton biomass in several reservoirs in Czechoslovakia, Int. Rev. ges. Hydrobio., 66, 153-169, 1981.

Ducklow, H. W., Baker, K., Martinson, D. G., Quetin, L. B., Ross, R. M., Smith, R. C., Stammerjohn, S. E., Vernet, M., and Fraser, W.: Marine pelagic ecosystems: the west Antarctic Peninsula, Philos. Trans. R. Soc. Lond. B. Biol. Sci., 362, 67-94, 2007.

Joughin, I., Smith, B. E., and Medley, B.: Marine ice sheet collapse potentially under way for the Thwaites Glacier Basin, West Antarctica, Science, 344, 735-738, 2014.

Kang, J. J., Joo, H. T., Lee, J. H., Lee, J. H., Lee, H. W., Lee, D., Kang, C. K., Yun, M. S., and Lee, S. H.: Composition of biochemical compositions of phytoplankton during spring and fall seasons in the northern East/Japan Sea, Deep-Sea Res. Pt. II, https://doi.org/https://doi.org/10.1016/j.dsr2.2017.06.006, 2017.

Kim, B. K., Joo, H., Song, H. J., Yang, E. J., Lee, S. H., Hahm, D., Rhee, T. S., and Lee, S. H.: Large seasonal variation in phyto- 
plankton production in the Amundsen Sea, Polar Biol., 38, 319$331,2015$.

Kim, B. K., Lee, J. H., Joo, H., Song, H. J., Yang, E. J., Lee, S. H., and Lee, S. H.: Macromolecular compositions of phytoplankton in the Amundsen Sea, Antarctica, Deep-Sea Res. Pt. II, 123, 4249, 2016.

Koike, I., Holm-Hansen, O., and Biggs, D. C.: Inorganic nitrogen metabolism by Antarctic phytoplankton with special reference to ammonium cycling, Mar. Ecol.-Prog. Ser., 30, 105-116, 1986.

Kruskopf, M. and Flynn, K. J.: Chlorophyll content and fluorescence responses cannot be used to gauge reliably phytoplankton biomass, nutrient status or growth rate, New Phytol., 169, 525536, 2006

Lee, S. H., Whitledge, T. E., and Kang, S.: Spring time production of bottom ice algae in the landfast sea ice zone at Barrow, Alaska, J. Exp. Mar. Biol., 367, 204-212, 2008.

Lee, S. H., Kim, B. K., Yun, M. S., Joo, H., Yang, E. J., Kim, Y. N., Shin, H. C., and Lee, S.: Spatial distribution of phytoplankton productivity in the Amundsen Sea, Antarctica, Polar Biol., 35, 1721-1733, 2012.

Lee, S. H., Yun, M. S., Kim, B. K., Joo, H., Kang, S.-J., Kang, C. K., and Whitledge, T. E.: Contribution of small phytoplankton to total primary production in the Chukchi Sea, Cont. Shelf Res., 68, 43-50, 2013.

Matrai, P., Vernet, M., Hood, R., Jennings, A., Brody, E., and Saemundsdóttir, S.: Light-dependence of carbon and sulfur production by polar clones of the genus Phaeocystis, Mar. Biol., 124, 157-167, 1995.

Moline, M. A., Claustre, H., Frazer, T. K., Schofield, O., and Vernet, M.: Alteration of the food web along the Antarctic Peninsula in response to a regional warming trend, Glob. Change Biol., 10, 1973-1980, 2004.

Montes-Hugo, M., Doney, S. C., Ducklow, H. W., Fraser, W., Martinson, D., Stammerjohn, S. E., and Schofield, O.: Recent changes in phytoplankton communities associated with rapid regional climate change along the western Antarctic Peninsula, Science, 323, 1470-1473, 2009.
Paolo, F. S., Fricker, H. A., and Padman, L.: Ice sheets. Volume loss from Antarctic ice shelves is accelerating, Science, 348, 327331, 2015.

Parsons, T. R., Maita, Y., and Lalli, C. M.: A manual of chemical and biological methods for seawater analysis, Publ. Pergamon Press, Oxford, 1984.

Robineau, B., Legendre, L., Therriault, J.-C., Fortier, L., Rosenberg, G., and Demers, S.: Ultra-algae $(<5 \mu \mathrm{m})$ in the ice, at the icewater interface and in the under-ice water column (southeastern Hudson Bay, Canada), 115, 169-180, 1994.

Saggiomo, V., Carrada, G., Mangoni, O., d'Alcala, M. R., and Russo, A.: Spatial and temporal variability of size-fractionated biomass and primary production in the Ross Sea (Antarctica) during austral spring and summer, J. Mar. Syst., 17, 115-127, 1998.

Schmidtko, S., Heywood, K. J., Thompson, A. F., and Aoki, S.: Multidecadal warming of Antarctic waters, Science, 346, 1227 1231, 2014.

Tremblay, J. É., Legendre, L., Klein, B., and Therriault, J.: Sizedifferential uptake of nitrogen and carbon in a marginal sea (Gulf of St. Lawrence, Canada): significance of diel periodicity and urea uptake, Deep-Sea Res. Pt. II, 47, 489-518, 2000.

Wassmann, P., Duarte, C. M., Agusti, S., and Sejr, M. K.: Footprints of climate change in the Arctic marine ecosystem, Glob. Change Biol., 17, 1235-1249, 2011.

Yager, P. L., Sherrell, L., Stammerjohn, S. E., Alderkamp, A., Schofield, O., Abrahamsen, E. P., Arrigo, K. R., Bertilsson, S., Garay, D., and Guerrero, R.: ASPIRE: the Amundsen Sea Polynya international research expedition, Oceanography, 25, 40-53, 2012. 